\title{
The Use of Vertical Representation in Students' Science Book on Matter Particles Topic and Its Impact on Students' HOTS and Visual Literacy
}

\author{
Ni Made Ratna Sari ${ }^{1}$, M. Setyarini ${ }^{2}$, Dewi Lengkana ${ }^{3}$, Tri Jalmo ${ }^{4}$ \\ \{nimaderatnasari@gmail.com ${ }^{1}$, m.setyarini.fkip.unila.ac.id ${ }^{2}$, dewilengkana76@gmail.com ${ }^{3}$ \} \\ Science Education, Magister Program, Lampung University ${ }^{1}$, Chemistry Education, Lampung \\ University $^{2}$, Biology Education, Lampung University ${ }^{3}$
}

\begin{abstract}
This study aimed to identify the use of vertical representation presented in students' science book in explaining scientific concepts, theories, and phenomena on matter particles and its impact on students' HOTS and visual literacy. The method used in this study is quantitatively descriptive method. The samples of this study were 100 students in ten senior high schools in Bandar Lampung and Central Lampung. The data collection used questionnaire and students' science book assessment sheet. The result showed that the teaching materials most widely used by student was students' science book of 2013 curriculum published by Ministry of Education and Culture which in the very high category $(96 \%)$. The type of vertical representation that was mostly presented in matter particles topic in the science book was symbolic level which in a very high category (82.22). The percentage of evaluation and student activities on the science book which accordance with HOTS indicators was in the low category $(26.08 \%)$, while in accordance with visual literacy indicators was in the very low category $(15.21 \%)$.
\end{abstract}

Keywords: Vertical representation, HOTS, visual literacy.

\section{Introduction}

In this $21^{\text {st }}$ century, the vast development of information technology affects various aspects of life in the society [1]. Within the sphere of education, technology provides many forms of digital facilities, which can of course make learning more attractive and interesting by way of visual dynamic and interactive [1],[2]. The students in this era are the generation having been living with technology as an inseparable part of life [3]. They make use of technology for playing games, studying, and finding abundant information on the internet. This technological development drives students to being the active consumers of such multimedia platforms as the internet, television, film, and commercials, which are dominated by visual information [4]. The internet offers convenience galore in acquiring aplenty information and necessary learning material for students.

Both learning material and visual information can spread super quickly and be downloaded almost effortlessly, without the consideration whether or not the information is in accordance with the fact. As a result, students acquire misleading information and it unquestionably flaws their knowledge. For this reason, it is of high urgency to train them in higher order thinking skills (HOTS) so that they will be able to tell right from wrong in terms of the material and information. In HOTS, it is required for them to optimally use their minds so as to be able to 
apply the information and knowledge they have acquired in order to solve the problems in their daily lives [5],[6]. Besides HOTS, students should also have the ability to read, interpret, and comprehend visual information presented in the forms of symbols, graphics, pictures, and videos in daily life, which is regarded as visual literacy [7].

It is possible to train students' HOTS and visual literacy through science learning at school. Science holds a vital role in improving the quality of education, especially in terms of producing excellent students, those who are able to think critically, creatively, logically, and handle social issues on their own initiative [8]. The results of the 2018 PISA and 2015 TIMSS demonstrated that Indonesian students' overall score achievement for science was way below the average [9],[10].

Science comprises abstract concepts, so it is still difficult for students to understand it. Therefore, it possibly turns into a cognitive burden for them. One of the abstract items of material in science lesson is matter particles topic. The concepts of matter particles topic are difficult if they are just imagined by students, and if the way the teacher delivers the lesson is not quite right, there will be students' different perceptions [11]. The phenomena of matter particles topic are difficult to be presented in class so that the representations which can visualize it are of essence. One of the possible types of representations is the vertical one. Via this type, the relationships between the scientific phenomena at the macro, sub micro, and symbolic levels can be described [12].

At the macro level, the representations are obtained from the observations of phenomena that can be seen directly. The macro level covers what is learnt and experienced in daily life [12]. The sub micro level is related to the representations explaining the observed macroscopic [13], while the symbolic level is composed of the qualitative abstractions used to represent each item at the sub micro level [13]. The purpose of this study is to identify the use of vertical representation presented in the secondary school science books in explaining scientific concepts, theories, and phenomena on matter particles topic and the impact on students' HOTS and visual leteracy.

\section{Materials and Methods}

The method used in this research was quantitatively descriptive method. The samples on this research were one hundred $10^{\text {th }}$ grade students in ten senior high schools in the city of Bandar Lampung and Central Lampung District. The data collected using questionnaire and students' science book assessment sheet for the nine-grade science book 2013 curriculum, published by the Ministry of Education and Culture in 2018. Criteria for data analysis results from student questionnaires and science book analysis are presented in Table 1. Analysis of students' science books is based on the use of vertical representations, aspects of HOTS according to indicators of HOTS by Anderson \& Krathwohl and visual literacy according to the visual literacy indicators by Avgerinou [14],[15]. HOTS indicators used were analyzing (C4), evaluating (C5), and creation (C6) [14]. Visual literacy used were visual thinking, visual reasoning, visual discrimination, and visual association [15]. The questionnaire is used to find out the teaching materials used by students. Students' science book assessment sheet was used to know the type of vertical representation on science book and determine its impact on HOTS and visual literacy achievement based on evaluation and students' activities on the book. 
The data analysis technique of the questionnaire usage of students learning materials was done by calculating the percentage of respondents' answers to each item using the following formula [16]:

$$
\% \mathrm{~J}_{\text {in }}=\frac{\sum \mathrm{Ji}}{\mathrm{N}} \times 100 \%
$$

Where \% Jin is the percentage of answer choices i, $\sum \mathrm{Ji}$ is the number of respondents who chose answer $\mathrm{i}$, and $\mathrm{N}$ is the total number of respondents.

The data analysis technique of the science's book assessment sheet was done by calculating the percentage using the following formula [16]:

$$
\% \mathrm{X}_{\text {in }}=\frac{\sum \mathrm{S}}{\mathrm{Smaks}} \times 100 \%
$$

Where $\% \mathrm{X}_{\text {in }}$ is the percentage of answer choices, $\sum \mathrm{s}$ is the total score answered on assessment sheet, and $S_{\text {maks }}$ is the maximum score.

The percentage criteria for data analysis results from student questionnaires and science book assessment sheets [17], are presented in Table 1.

Table 1. Questionnaire criteria for the use of teaching materials by students and Science book analysis data on matter particels topic

\begin{tabular}{cl}
\hline Percentage (\%) & \multicolumn{1}{c}{ Criteria } \\
\hline $80,1-100$ & Very high \\
$60,1-80$ & High \\
$40,1-60$ & Medium \\
$20,1-40$ & Low \\
$0,0-20$ & Very low \\
\hline
\end{tabular}

\section{Result}

The results of the data analysis questionnaire of the teaching material used by students in material particles topic are presented in Figure 1.

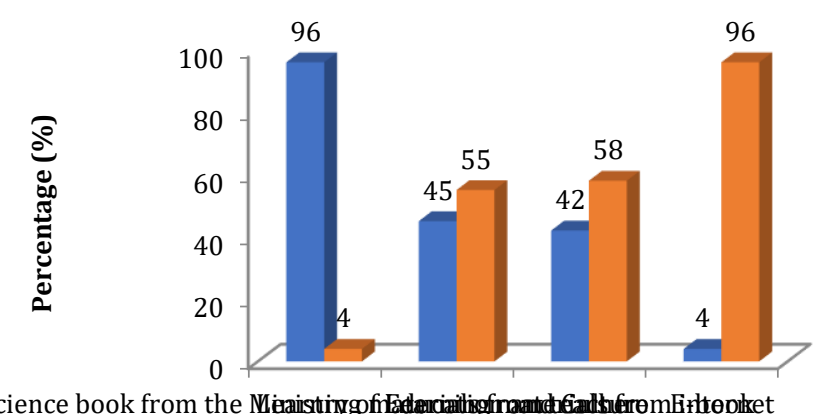

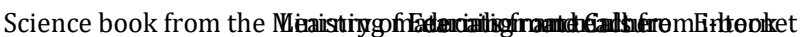

$\square$ Yes No

Fig. 1. Teaching materials used by students in matter particles topic 
The results of the vertical representation data analysis presented in the science book published by the Ministry of Education and Cultre in 2018 are presented in Figure 2.

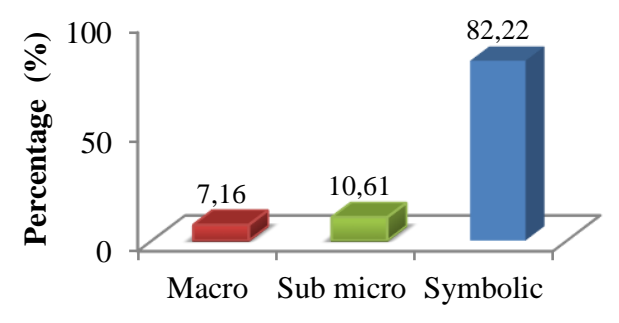

Fig. 2. Vertical representation in the science book published by the Ministry of Education and Cultre

The percentage of evaluation and student activities on the Ministry of Education and Cultre's science book on matter particles topic are presented in Figure 3.

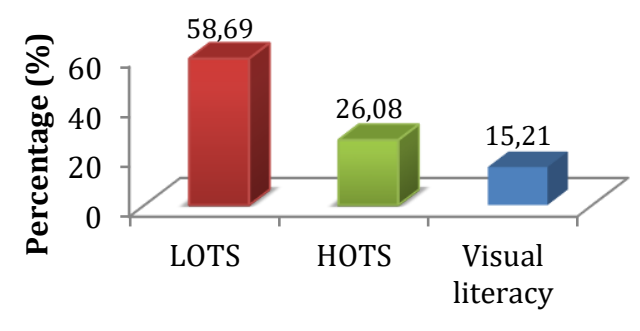

Fig. 3. Percentage of question types presented science book on matter particles topic

Percentage indicators of HOTS in the evaluation and student activities on the science book on matter particles topic are presented in Figure 4.

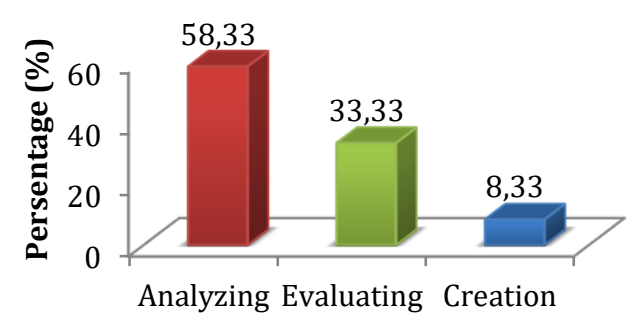

Fig. 4. Percentage indicator of HOTS presented in the science book on matter particles topic

Percentage indicators of visual literacy in the evaluation and student activities on the science book on matter particles topic are presented in Figure 5. 


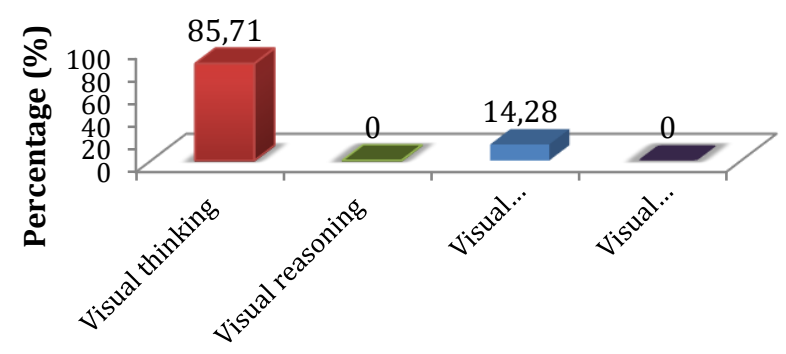

Fig 5. Percentage indicator of visual literacy presented in the science book on matter particles topic

\section{Discussion}

One of the basic competencies of science learning in the third year of junior high school, or the ninth grade, based on the revised 2013 curriculum was to relate the concepts of matter particles (atoms, ions, molecules), simple substance structure to the nature of material used in daily life, and the impact of the use on humans' health [18]. The theories of matter particles are the core of the science curriculum at school [19]. According to Figure 1, the form of learning material used the most by the respondents (students) for the matter particles topic are the science book published by Ministry of Education and Culture in 2018 are in the very high category (96\%). Student who use teaching materials from teacher are in the medium category (48\%), students who use teaching materials from the internet are in the medium category $(45 \%)$ while e-books are in very low category (4\%). The science book from Ministry of Education and Culture is published in printed books and is not equipped with an interactive feature, which can enhance students' learning independence.

Assisting students with the use and interpretation of representations plays a vital role in science. Representations can help them to really comprehend scientific phenomena in real live [20]. In Figure 2, it can be seen that dominant vertical representations exist in the book published by Ministry of Education and Culture is the symbolic level with the very high category $(82.22 \%)$, while the macro level is in the very low category $(7.16 \%)$ and the sub-micro level with very low category $(10.16 \%)$. The phenomenon on the topic of matter particles is abstract so that it is difficult to present in classroom learning. The particles that make up materials (atoms, ions, molecules) are abstract and of course they cannot be seen directly so they need help to learn them, namely using vertical representations.

The benefit of using vertical representations is to be able to demonstrate the relations between the phenomena at the macro, micro, sub micro, and symbolic levels [12]. The vertical representations at the four levels can be described in proportion and the phenomena relating to the topic of matter particles are visualized well with them. This idea is backed up by Fadiawati and Tania's finding that the three levels of chemical representations (symbolic, macroscopic, and sub microscopic) should be described together in order for students to have a good understanding of the material [21]. Adadan deduces that the science learning involving multiple representations is proven effective in improving and preserving students' scientific understanding [19].

It is a sound inference that the use of vertical representations to elucidate everyday phenomena is undeniably essential. Water is one example. Water in a glass, which is visible 
without any aids, is still within the macro level. Its hydrogen bond is within the sub micro level, and the $\mathrm{H}_{2} \mathrm{O}$ chemical formula (less commonly, $\mathrm{H}-\mathrm{O}-\mathrm{H}$ ) can be used to represent the basic particles of water [22]. Students have a chance to analyze the micro level of water and train themselves to think visually, changing information from pictures, graphics, or others, which contributes to communicating the acquired information [15].

The total number of student activities and practice questions presented in the science book published by the Ministry of Education and Cultre are 46 questions. Referring to Figure 3, it can be seen that student activities and practice questions are still identified as evaluating LOTS in the medium category (58.69\%). Student activities and practice questions that train HOTS in the low category $(26.08 \%)$ and visual literacy in the very low category $(15.21 \%)$. The percentage of student activities and practice questions which train students' HOTS and visual literacy in the book published by Kemendibud are in Pictures 4 and 5.

From Figure 4, it is known that the student activities and exercise questions presented in the science book published by the Ministry of Education and Cultre which can improve students' HOTS in the book cover the following indicators: 1) analyzing, which falls into the medium category $(58.33 \%), 2$ ) evaluating, which falls into the low category $(33.33 \%)$, and 3) creation, which falls into the very low category $(8.33 \%)$. HOTS make it possible for students to see the concepts holistically and apply their ideas effectively to solve problems in real life [23]. HOTS are involved in the process of supplying new knowledge by way of skills, critical thinking strategies, and creative thoughts. It is unquestionably essential to lead students' thinking skills to improvement through science learning at school.

Figure 5 indicates that the student activities and exercise questions in the scince book published by the Ministry of Education and Cultre have not yet provided adequate training in visual literacy with respect to the visual reasioning indicator and visual association, while visual thinking is categorized as very high $(85.71 \%)$, and visual discrimination is categorized very low (14.28\%). Transitioning text to a visual format can reduce the cognitive load on students by providing clarity on complex concepts so that they are easier for students to understand [24]. Visual literacy is the ability to change visuals into verbal language, or vice versa, so that visual messages are formed [22]. According to Kiper et al., the characteristic of someone with enough visual literacy is that they are able to interpret, comprehend, and relate visual messages so that they figure out the concept of and solution to the encountered problem [25]. Visual literacy is identified as the prominent form of literacy society must have in the $21^{\text {st }}$ century [25-26].

\section{Conclusion}

Based on the results and discussion, it could be concluded that the teaching material most widely used by student on the learning of matter particle topic were science book 2013 curriculum published by the Ministry of Education and Culture. Science books used by students are equipped with a vertical representation, its still dominated by the symbolic level with the very high category while the macro and sub micro levels with the very low category. The vertical representation in matter particels topic in science book had not been used optimally to improve students' higher order thinking skills and visual literacy because its still dominated by the symbolic level. The percentage of student activities and practice questions its still dominated by the LOTS indicators, while HOTS indicators in the low category and visual literacy indicators in the very low category. Visual literacy indicators that were not presented on matter particles topic in the science books were visual reasioning and visual 
asosiation. Whereas the use of vertical representations with makro, submicro, and symbolik levels can it easier to understand abstrack concept in matter particles topic and also could train stdents' higher order thinking skills and visual literacy. HOTS and visual literacy are very important for students to be able to compete in the 21 st century, so needed a book could practice HOTS and visual literacy.

\section{References}

[1] Lai, C. S. Integrating E-Books into Science Teaching by Preservice Elementary School Teachers. Jornal of Education in Science, Environment and Health. 2016; 2(1). 57-66.

[2] Varma, K. \& Linn, M. C. Using Interactive Technology to Support Students' Understanding of the Greenhouse Effect and Global Warming. Journal of Science Education and Technology. 2012. 21(4): 453-464.

[3] Batoon, P., Victoria, M., Glasserman Morales, L. D., \& Yanez Figueroa, J. A. Instructional Design to Meansure the Efficacy Interactive E-Books in a High School Setting. Turkish Online Journal of Distance Education. 2018; 19(2): 47-60.

[4] Lundy, A. D. \& Stephens, A. E. Beyond The Literal: Teaching Visual Literacy in The 21st Century Classroom. Procedia Social and Behavioral Science. 2015: 157-160.

[5] Heong, Y. M., Othman, W.D., Md Yunos, J., Kiong, T.T., Hassan, R., \& Mohamad, M.M. The Level of Marzano Higher Order Thinking Skills Among Technical Education Students. International Journal of Social and Humanity. 2011; 1(2): 121-125.

[6] Siado, G. M., Siraj, S., Nordin, A. B. B., \& Al-Amedi, O. S. Higher Order Thinking Skills Among Secondary Students in Science Learning. The Malaysian Online Journal of Educational Science. 2018; 3(3): 13-20.

[7] Kipper, A., Arslan, S., Kiyici, M., \& Akgun, O. E. Visual Literacy Scale: The Studi of Validity and Reliability. The Online Journal of New Horizons in Education. 2012; 2(2); 73-83.

[8] Rohana, R. S. \& Wahyudin, D. Problem Based Learning untuk Meningkatkan Berpikir Kreatif Siswa SD pada Materi Makanan dan Kesehatan. Jurnal Penelitian Pendidikan UPI. 2016; 12(3): 235-243.

[9] Nizam. Ringkasan Hasil-Hasil Asesmen Belajar dari UN, PISA, TIMSS, INAP. Jakarta: Puspedik; 2016.

[10] Puspendik. Hasil PISA 2018. Jakarta: Depdiknas; 2018.

[11] Utomo, A. B., Fadiawati, N., Rosilawati, I., \& Kadaritna, N. Pengembangan Buku Ajar Partikel Materi Berbasis Representasi Kimia. Jurnal Penididkan dan Pembelajaran Kimia. 2013; 2(3): 1-12.

[12] Tsui, C. Y., \& Treagust, D. F. Introduction to multiple representations: Their importance in biology and biological education. Multiple representations in biological education. Dordrecht: Springer; 2013. 3-18.

[13] Gilbert, J.K., Reiner, M., \& Nakhleh, M. Visualization: Theory and Practice in Science Education. Springer; 2008.

[14] Anderson, L. W \& Krathwohl, D. R. A. Taxonomi of Learning, Taching, and Assesing: A Revision of Bloom's Taxonomy of Educational Objectives. New York: Longman; 2001.

[15] Avgerinou, M. D. Re-Reviewing Visual Literacy in "Bain d' Images Era. Tech Trends. 2009; 53(2): 28-34.

[16] Sudjana. Metode Statistika. Bandung: Tarsito; 2005.

[17] Arikunto. Dasar-dasar evaluasi pendidkan edisi revisi. Jakarta: Bumi Aksara; 2010.

[18] Kemendikbud. Kompetensi Inti dan Kompetensi Dasar Pelajaran pada Kurikulum 2013 Revisi Pendidikan Dasar dan Menengah. Jakarta: Kementrian Pendidikan dan Kebudayaan; 2018.

[19] Adadan, E. Using Multiple Representation to Promote Grade 11 Stuents' Scientific Understanding of The Particle Theory of Matter. Research in Science Education. 2012; 43(3): 1079-1105.

[20] Gillies, R. M., \& Rafter, M. Using Visual, Embodied, and Language Representation to Teach The 5E Instructional Model of Inquiry Science. Teaching and Teacher Education. 2020; 87: 102951.

[21] Fadiawati, N. \& Tania, L. The Development of Interactive E-Book Based Chemistry Representation Referred to The Curriculum of 2013. Indonesian Journal of Science Education. 2015; 4(2): 164-169. 
[22] Rundgren, S. N. C. \& Yao, B. Visualization in Research and Science Teachers' Professional Development. Asian-Facipic forum on Science learning and Teaching. 2014; 15(2): 1-21.

[23] Shukla, D. \& Dungsungneon, A. P. Students' Perceived Level and Teachers' Teaching Strategies of Higher Order Thinking Skills: A Study on Higher Educational Institutions in Thailand. Journal of Education and Practice. 2016; 7(12): 211-219.

[24] Metros, S. E. The Educator's Role in Prepering Visually Literate Learners. Theory Into Practice. 2008; 47(2): 102-109.

[25] Kiper, A., Arslan, S., Kiyici, M., \& Akgun, O. E. Visual Literacy Scale: The Study of Validity and Reliability. The Online Journal of New Horizons in Education. 2012; 2(2): 73-83.

[26] Fried, D.B., Tinio, P P. L., Gubi, A., \& Gaffney, J. P. Enhancing Elementary Science Learning Through Organic Chemistry Modeling And Visualization. European Journal of Science and Mathematic Education. 2019; 7(2): 73-82. 